\title{
Study on Vegetative Attributes and Yield Components of Mungbean (Vigna radiata L. Wilczek) Influenced by Plant Growth Regulators
}

\author{
Rowndel Khwairakpam* and Arun Kumar
}

Department of Crop Physiology, CSAUAT, Kanpur, Uttar Pradesh, India

*Corresponding author

\begin{tabular}{|c|}
\hline Keywords \\
\hline $\begin{array}{l}\text { Vegetative } \\
\text { attributes, Yield } \\
\text { components, } \\
\text { Mungbean (Vigna } \\
\text { radiata L. Wilczek) }\end{array}$ \\
\hline Article Info \\
\hline $\begin{array}{l}\text { Accepted: } \\
\text { 10 June } 2019 \\
\text { Available Online: } \\
\text { 10 July } 2019\end{array}$ \\
\hline
\end{tabular}

\section{A B S T R A C T}

The use of Plant Growth Regulators (PGRs) has opened up fresh opportunities for enhanced seed production in pulses in particular which are often face limitations due to intrinsic and external factors. Therefore, an experiment was carried out inside the net house in cement moulded pots to determine the effect of crop growth regulators viz. Maleic Hydrazide, Gibberellin, Triacontanol, 2,3,5triiodobenzoic acid and Cycocel, as foliar spray. The result indicated significant variations in foliage, canopy structure, floral initiation, pod setting, seeds per plants etc., due to plant growth regulators. These changes translated finally to the yield attributes. The results of the study concluded that productivity and Biological yield per plant was the highest among all treatments in case of $20 \mathrm{ppm}$ TIBA, although H.I. was highest in CCC $100 \mathrm{ppm}$. These results suggest that utilization of plant growth regulator might serve us a means of improving yield of mung bean. This investigation also indicated that if a new growth inhibitor were to be recognized, which could control excess vegetative growth without negative. Effects on reproductive development, seed yield in mung bean, it could also possibly be improved by combining a growth inhibitor such as TIBA with growth promoter at a specific developmental stage.

\section{Introduction}

Owing to its nutritional content of proteins, vitamins B, minerals, digestibility, and dietary fibers mungbean consists of an indispensable dietary component in regions of the Indiansubcontinent.

Its inherent ability to fix atmospheric nitrogen into the soil makes it a desirable candidate for intercropping and rotational cropping with cereals and various non-leguminous crops during Rabi (South India), Kharif and Zaid seasons (Arun et al., 2019). The area under mung bean cultivation in India is $3.02 \mathrm{~m}$ ha with a production of $1.50 \mathrm{~m}$ tons and productivity $298.0 \mathrm{~kg} / \mathrm{h}$. In U.P., it occupies 88.0 ha area with the production of 46.0 tons and productivity $523.0 \mathrm{~kg} / \mathrm{h}$. Plant regulators can impose both positive and negative regulation on plants. In the past few years, besides the best effort mungbean productivity 
has persisted static and the gap between supply and demand has deepened (Gowda et al., 2013). These stagnation of productivity besides the best-recommended practice is due to natural and physiological constraints such as poor germination, source limitation, slow dry matter accumulation, indeterminate growth habit, $\mathrm{C}_{3}$ photosynthetic apparatus, decrease in nodule activity, abscission of flowers and pods, higher energy requirement and reduced sink activity (Deol et al., 2018). Application of appropriate dose of certain plant growth regulators in the specific growth stage can upheave these constraints by elevating the limitation factors as reported by various studies. GA plays an important role in supplying stored assimilates in the germinating seeds to the growing embryo, thus significantly improves germination percentage and ensures proper plumule and radicle development.

TIBA is known to stimulate photosynthesis due to higher assimilative area production which leads to ensures better growth, development, and higher yield. Parmar et al., (2012). TIBA is used to monitor excessive vegetative growth and lodging, reduce flowers and immature pods abscission, and modify plant canopy to enhance crop productivity (Adam and Jahan 2014). Triacontanol (TRIA) and Cycocel (CCC) have been reported to improve yield by inhibiting floral abscission thus leading to a higher number of flower that eventually reflects its yield. TRIA has been reported to have a profound effect on increasing seed weight. Cycocel is known at sufficient concentration to counteract the effect of indigenous $\mathrm{ABA}$ and reduce the percentage of shedding (Singh et al., 2017). Maleic Hydrazide (MH) improved dry matter accumulation in certain legumes. Thus suggesting that these substances have the potential of dealing with physiological limitations of pulses and enhancing their productivity.

\section{Materials and Methods}

The mungbean variety used in this study was "Samrat" which was procured from the Research cum Seed Production Farm CSAUAT, Kanpur. Experimental was conducted in cemented pots of $25 \mathrm{~cm}^{2}$ filled with $8 \mathrm{Kg}$ of soil each. The bottom holes were covered with pieces of broken pot well pulverized and air-dried soil was filled in the pots and compacted after filling. The recommended fertilizers, @ $15 \mathrm{Kg} \mathrm{N}$. $40 \mathrm{Kg}$ $\mathrm{P}_{2} \mathrm{O}_{2} /$ ha were applied as per split doses, half quantity basal and another half as a top dressing. The experiment was laid out in Complete Randomized Design (CRD).

\section{Preparation of Solution and Spraying}

The plant growth regulators were prepared by standard calculations after measuring the necessary amount for the different doses by first dissolving it in few drops of ethyl alcohol stirring well, made a paste and then made up the volume for $1000 \mathrm{ml}$ with distilled water separately. The solutions were stored in a well-stoppered flat bottom flask of capacity 1 liter ready before use. Solutions added with adhesive tween $20 @ 0.1 \%$. Control pots were treated with distilled water along with Tween20. Foliar applications were carried out at initial flowering and full flowering using an atomizer at a different screened makeshift chamber to avoid unwanted contact.

\section{Detail of treatment}

Each of the plant growth regulator were prepared into two concentrations, i.e. ten (10) treatments, one control namely, Maleic Hydrazide (50 ppm and $100 \mathrm{ppm}$ ), Gibberellin (20 ppm and $40 \mathrm{ppm}$ ), Triacontanol (2 ppm and $4 \mathrm{ppm})$, Cycocel (50 ppm and $100 \mathrm{ppm}$ ), 2,3,5-triiodobenzoic acid (20 and $40 \mathrm{ppm}$ ) Control (distilled water) into four replications each treatment were delivered through foliar 
spray at 30 and 45 days after sowing. The plant parts were separated into leaves, stems and roots.

\section{Leaf area index (LAI)}

Since the crop yield is to be assessed per unit ground area instead of per plant, the leaf area existing on unit ground area was proposed by Watson (1952). Leaf area index is the ratio of leaf area to ground area occupied by crop plant. Leaf area index plant $^{-1}$ was calculated by using the following formula.

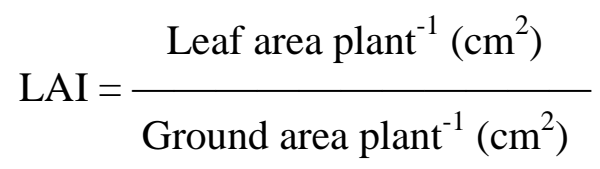

\section{Harvest Index}

$$
\begin{aligned}
& \text { Harvest Index (\%) } \\
& \frac{\text { Economic Yield }_{(\text {Grain) }}}{=\text { Biological Yield }_{(\text {Total Dry Matter) }}} \text { X } 100
\end{aligned}
$$

\section{Results and Discussion}

\section{Plant Height and number of branches}

The tallest plant height was attained by both the GA treatments at 60 DAS thus both treatment have similar effect in respect to plant height. Whereas TIBA treated plant were found to have significant reduction in height from the shortened internodes in comparison to the control plants throughout the stages. The main stem height was significantly reduced and the number of branches per plant and the number of nodes on branches increased with TIBA treatment.

\section{Number of leaves and total leaf area}

The number of leaves serves as source of photosynthesis, so has a direct impact on the sink's capacity and determines the plant's output. As a result of plant growth regulators the number of leaves per plant attained maximum in TIBA $20 \mathrm{ppm}$ treatment at 50 DAS whereas at GA 40 ppm influence was reflected in terms of leaves numbers and leaf area as observed by Emongor (2007).

MH treatment had a negative impact on the numbers count of the leaves which tend to increase with increase in concentration and were recorded significantly lower than the controls throughout the growth stages. Plant growth regulator affected the leaf expansion and leaf numbers between post flowering initiation and before maturity stages. In CCC 100 ppm plants at 60 DAS stages, the highest leaf area per plant was recorded followed by TRIA 2 ppm and GA $40 \mathrm{ppm}$, projecting the higher biological yield in the same treatments. Within low ppm treatments in GA, TRIA, TIBA the effect was less noticeable whereas between the treatments the difference were significant and conclusive.

\section{Vegetative dry weight}

The dry weight accumulation was determined by measuring leave and stem dry weight which remain in similar trend as in the result of the total leaf area. The dry matter in trifoliate and stem were found to be highest in CCC 100 ppm treatments closely followed by TRIA throughout the stages. The result of CCC $50 \mathrm{ppm}$ treatment resulted to lesser profound effect than that of CCC 100 ppm.MH treatments were least affected by the treatments.

\section{Leaf Area Index (LAI)}

LAI steadily increased even after flowering and were highest at around 60 DAS then it gradually declined. LAI were recorded similar in trend to the leaf area, with CCC $100 \mathrm{ppm}$ being the highest of all treatment followed by TRIA 4 ppm and GA 40 ppm. 

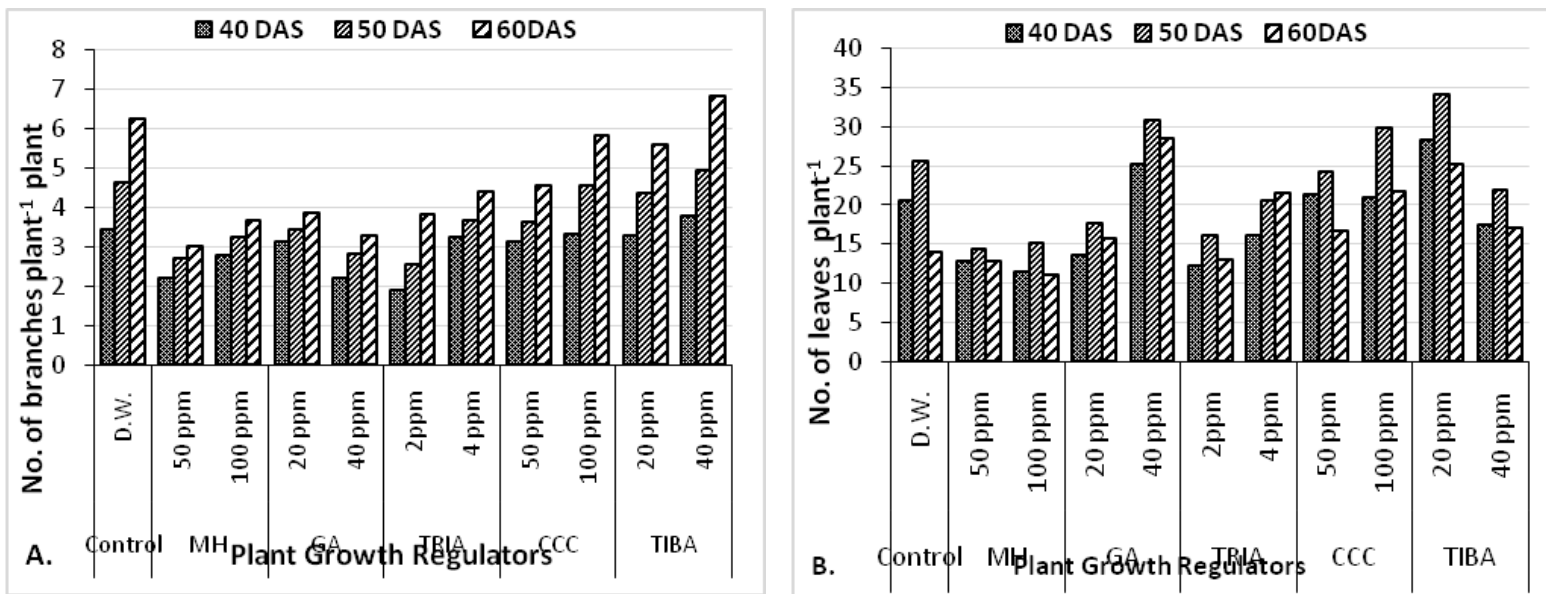

Fig.1-Effect of plant growth regulators on A. no. of branches, B. no. of leaves
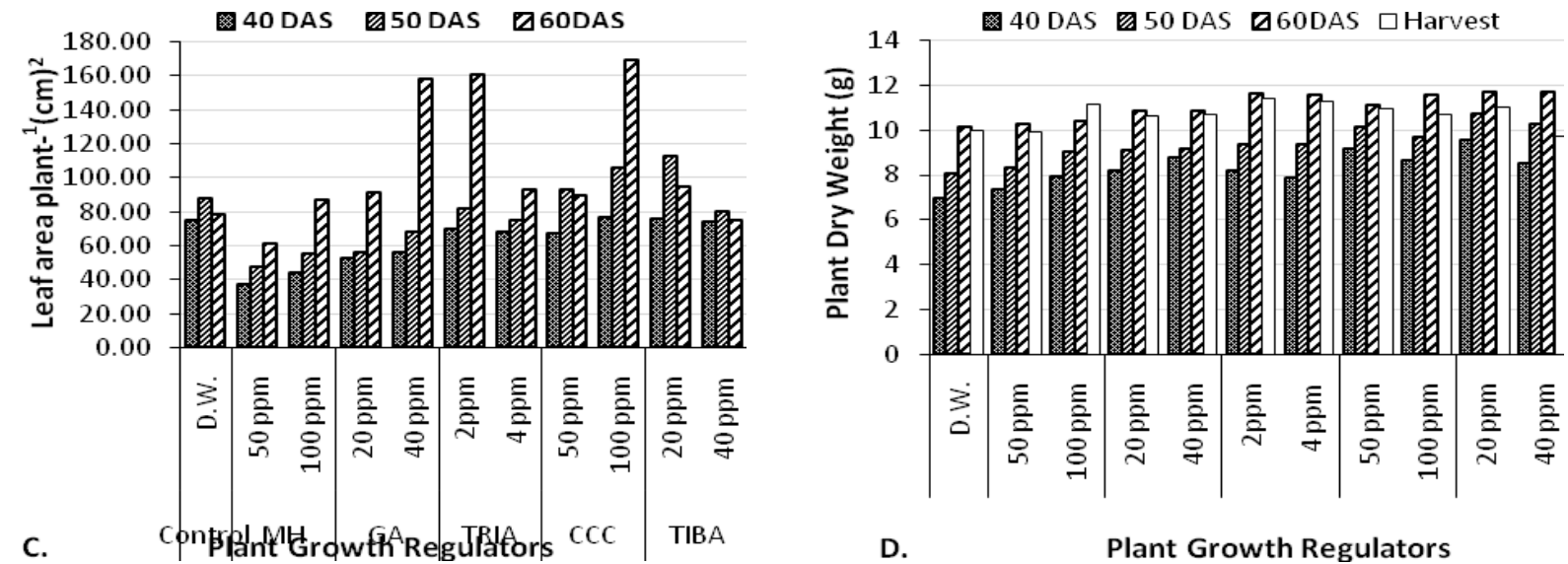

Fig.2-Effect of plant growth regulators on C. Leaf area, D. Plant dry weight.

Table.1 Effects of plant growth regulators on LAI, seed yield plant, biological yield plant, H.I., Productivity

\begin{tabular}{|c|c|c|c|c|c|c|}
\hline \multicolumn{2}{|c|}{$\begin{array}{l}\text { Treatment } \\
\text { in ppm }\end{array}$} & $\begin{array}{l}\text { LAI at } 60 \\
\text { DAS }\end{array}$ & $\begin{array}{c}\text { Seed yield } \\
\text { plant }^{-1} \text { in (g.) }\end{array}$ & $\begin{array}{c}\text { Biological yield plant } \\
(\mathrm{g} .)\end{array}$ & $\begin{array}{l}\text { H.I. } \\
(\%)\end{array}$ & $\begin{array}{l}\text { Productivity } \\
\mathrm{g}^{-1} \text { day }^{-1} \text { plant }^{-1}\end{array}$ \\
\hline \multirow[t]{2}{*}{ MH } & $50 \mathrm{ppm}$ & 1.7 & 5.5 & 36.1 & 24.5 & 0.082 \\
\hline & $100 \mathrm{ppm}$ & 1.4 & 6.8 & 36.6 & 25.2 & 0.085 \\
\hline \multirow[t]{2}{*}{ GA } & $20 \mathrm{ppm}$ & 1.9 & 6.7 & 36.9 & 25.6 & 0.084 \\
\hline & $40 \mathrm{ppm}$ & 3.5 & 6.9 & 36.4 & 26.0 & 0.086 \\
\hline \multirow[t]{2}{*}{ TRIA } & $2 \mathrm{ppm}$ & 3.5 & 6.8 & 36.1 & 25.8 & 0.086 \\
\hline & $4 \mathrm{ppm}$ & 2.6 & 6.7 & 37.7 & 24.1 & 0.084 \\
\hline \multirow[t]{2}{*}{ CCC } & $50 \mathrm{ppm}$ & 3.4 & 6.7 & 38.4 & 26.2 & 0.083 \\
\hline & $100 \mathrm{ppm}$ & 3.8 & 7.8 & 38.6 & 27.0 & 0.093 \\
\hline \multirow[t]{2}{*}{ TIBA } & $20 \mathrm{ppm}$ & 3.1 & 7.9 & 39.5 & 26.9 & 0.091 \\
\hline & $40 \mathrm{ppm}$ & 3.0 & 7.4 & 39.4 & 25.5 & 0.098 \\
\hline Control & Water & 1.7 & 7.3 & 22.6 & 24.6 & 0.099 \\
\hline S.Ed $( \pm)$ & & 1.7 & 0.316 & 0.98 & 0.44 & 0.0077 \\
\hline C.D. $(5 \%)$ & & 3.5 & 0.654 & 2.00 & 0.89 & 0.0157 \\
\hline
\end{tabular}


TIBA, both the treatment showed a relatively higher LAI then the control and $\mathrm{MH}$ treatments.

This is due to reduction abscission of floral buds and leaf, which will translate finally to the yield and photosynthetic source by modification of the canopy structure that optimizes productivity (Adam and Jahan 2014)

\section{Seed yield per pod and Seed yield per plant}

A critical examination of seed yield data displayed in the (Table 1) revealed that spraying of growth regulators on mung bean plant produced significantly more seed yield over control plants.

Maximum seed yield per plant was recorded by the treatment of TIBA 40ppm followed by TIBA-20ppm, closely followed by CCC 50 ppm and CCC $100 \mathrm{ppm}$. TIBA treatments are found to improve pod setting and seed filling similar to the results of Jahan (2014).

\section{Harvest index}

Persual of data present in (Table 1) imparted image that maximum harvest index was recorded with CCC $100 \mathrm{ppm}$ closely followed by TIBA $20 \mathrm{ppm}$ and CCC 50ppm whereas MH $100 \mathrm{ppm}$ gave least position in this regard.

\section{Productivity}

Pertaining to the data the highest productivity was found to be for treatment TIBA $40 \mathrm{ppm}$ closely followed by $20 \mathrm{ppm}$. TIBA was at par with the productivity of CCC.

MH $50 \mathrm{ppm}$ productivity was insignificant to the productivity of the control. GA was significant to the control but was at par to that of MH 100 ppm, TRIA 2ppm, TRIA 4 ppm.

\section{References}

Adam AG, Jahan N. 2014. Growth and yield of bari mung-5 (Vigna radiate L. Wilczek) following TIBA application. Dhaka University Journal of Biological Sciences. 23(2): 179-185.

Bora RK, Sarma CM. 2006. Effect of gibberellic acid and cycocel on growth, yield and protein content of pea. Asian Journal of Plant Sciences. 5(2): 324330.

Chandrasekhar C.N. and Bangarusamy U. 2003. Maximizing the yield of mung bean by foliar application of growth regulating chemicals and nutrients. Madras Agricultural Journal. 90(1/3): 142-145.

Chovatia RS, Ahlawat TR, Kavathia YA, Jivani LL, Kaila DC. 2010 Effect of plant growth regulators on vegetative growth, flowering and yield of bitter gourd cv. Priya. Indian Journal of Horticulture. 67(4): 254-258.

Das A, Prasad R. 2004.Effect of plant growth regulators on green gram (Phaseolus radiatus). ICAR publications. 74(5): 271-2.

Gowda, C.L. and Laxmipathi. 2013. Enhancing the productivity and production of pulses in India. Climate Change and Sustainable Food Security, NIAS and ICAR. 145-159.

Hoque M, Haque S. 2003 Effects of GA3 and its mode of application on morphology and yield parameters of mungbean (Vigna radiate L.). Pakistan Journal of Biological Science. 5(3): 281-283.

Jahan, Nargis\& Adam, A. M. M. Golam. 2011. Comparative Growth Analysis of two Varieties of Rice Following Naphthalene Acetic Acid Application. Journal of Bangladesh Academy of Sciences. 35. 10.3329/jbas.v35i1.7976.

Jahan, Nargis, and Salma Khan.2014. "Effect of TIBA on growth, yield and yield 
component of soybean." J. Asiat. Soc. Bangladesh, Sci 40: 89-96.

Kshirsagar S.S., Chavan B.N., Sawargaonkar G.L. and Ambhore S.S. 2008. Effect of cycocel on growth parameters of green gram (Vigna radiata) cv. BPMR-145. International Journal of Agriculture Science. 4(1): 346-347.

Kumar P., Hiremath S.M., Deshmukh P.S., and Kushwaha S.R. 2002 Effect of growth regulators on growth yield and metabolism in soybean genotypes. Indian Journal of Agricultural Research. 36(4): 254-258.

Kumar R., Yadav R.K., Sharma N., and Nehal $\mathrm{N}$. Influence of plant growth regulators on yield and yield attributes of mungbean (Vigna radiate L. Wilczek). Journal of Pharmacognosy and Phytochemistry. 2018; SP2: 98-100.

Kumari P. 2014. Effect of foliar application of plant growth regulators on photo assimilate partitioning, growth, yield and quality of pigeonpea [Cajanus cajan (L.) millsp.] (Doctoral dissertation, JNKVV).
Parmar, V. K. Dudhatra, M. G. and Thesiya, N. M., 2012. Effect of growth regulators on yield of summer greengram. Legume. Res., 34 (1): 65-67.

Ramesh R, Ramprasad E. 2015. Effect of plant growth regulators on morphological, physiological and biochemical parameters of soybean (Glycine $\max \quad$ L. Merrill). In Biotechnology and Bioforensics. 2015, 61-71.

Sumathi A., Prasad V.B.R., and Vanangamudi M. 2016 Influence of plant growth regulators on yield and yield components in pigeonpea. Legume Research. 40(4):392-398.

V. Emongor, 2007. Gibberellic Acid $\left(\mathrm{GA}_{3}\right)$ Influence on Vegetative Growth, Nodulation and Yield of Cowpea (Vigna unguiculata (L.) Walp.) Journal of Agronomy, 6: 509-517.

Yadav M.S., and Dhanai C.S.2016 Impact of varietal and growth regulator treatments on morpho-physiological characters and quality of mungbean (Vigna radiate (L.) Wilczek). Environment and Ecology. 34(3C):1591-1597.

\section{How to cite this article:}

Rowndel Khwairakpam and Arun Kumar. 2019. Study on Vegetative Attributes and Yield Components of Mungbean (Vigna radiata L. Wilczek) Influenced by Plant Growth Regulators. Int.J.Curr.Microbiol.App.Sci. 8(07): 1051-1056. doi: https://doi.org/10.20546/ijcmas.2019.807.126 